\title{
LAYANAN BIMBINGAN BELAJAR SEBAGAI UPAYA PENINGKATAN KUALITAS PROSES BELAJAR-MENGAJAR
}

\author{
Zaenal Abidin \\ Korespondensi: Jl. Jenderal Ahmad Yani No. 40A, Purwokerto, Jawa Tengah
}

\begin{abstract}
According to the real result of the various studying difficulties, which being felt by the client (student), whatever their reasons or motives are very much demand to the guider to take part in looking for the various alternatives in order to help the student resolving those cases through the learning guidance services actively. This activity is in order to create the student's mental stability and their readiness to promote their aptitude and full participation, especially in learning process (in the class). If this condition can be realized be expected to obtain the quality of learning-teaching process in the class.
\end{abstract}

Kata kunci: learning guidance, learning process, enhancing learning quality effort.

\section{PENDAHULUAN}

$\mathrm{P}$ ada prinsipnya setiap siswa memiliki hak dalam mencapai prestasi akademik yang memuaskan. Namun dalam realitas sehari hari setiap siswa memiliki berbagai perbedaan dalam berbagai aspek seperti perbedaan intelektual, bakat, minat, kemauan, perhatian, latar belakang, partisipasi anak dikelas, partisipasi orang tua dalam mendorong dan memotivasi anaknya untuk belajar, sikap dan kebiasaan belajar yang terkadang perbedaannya sangat mencolok antara satu dengan yang lainnya.

Sementara itu penyelenggara pendidikan sekolah pada umumnya lebih ditujukan perhatiannya kepada siswa yang berkemampuan rata rata, sehingga siswa yang berkemampuan dibawah rata rata atau siswa yang memiliki kemampuan diatas rata rata (siswa yang bodoh ataupun yang terlalu pintar) belum dapat pelayanan akademik memadai untuk mengembangkan seluruh potensinya yang sesuai kapasitasnya, mengingat system pembelajran masih bersifat klasikal, kelompok. Jadi kesulitan belajar siswa yang jelas bodoh ataupun siswa yang terlalu cerdas tidak bisa ditangani secara proporsional dan professional, bila hanya mengandalkan atau dibebankan kepada guru mata pelajaran saja. Belum lagi berbagai kesulitan belajar yang dialami oleh siswa berkemampuan rata rata juga tidak selamanya berjalan mulus dalam menjalankan tugas belajarnya baik disekolah maupun di rumah.

Kondisi kesulitan belajar yang muncul dari kondisi siswa keseluruhannya dimaksud bisa terjadi disebabkan oleh berbagai faktor internal maupun eksternal siswa. Faktor internal bisa saja meliputi: kelambanan dalam belajar, ketercepatan dalam belajar, kondisi emosi yang kurang stabil, ataupun gangguan psikomotoriknya. Sedangkan faktor eks- 
ternalpun banyak yang turut campur berdampak negative bagi kemajuan belajar siswa diantaranya adalah fakktor perhatian orang tua, fasilitas, lingkungan keluarga yang kurang memberikan dukungan dalam peklaksanaan tugas belajar siswa, lingkungan masyarakatnya yang masa bodoh, lingkungan budaya, yang sering terdengar bahwa sekolah itu membuang duit, lingkungan kemajuan tehnologi disekitar keidupan kita yang serba canggih ini terutama sajian menu handpone, internet yang memberikan jaminan dengan permainan permainan yang menyenangkan siswa dan sebagainya. Atas dasar realitas tersebut menuntut guru pembimbing secara serius untuk menangani dan mengantisipasi kondisi ini tentu dengan penuh kerjasama dengan berbagai fihak baik seluruh personil di sekolah maupun lingkungan masyarakat disekitar sekolah dan juga perangkat desa didekat sekolah.

Dengan segala upaya dimaksud diharapkan segera dapat mendorong dan meningkatkan kualitas proses belajarmengajar yang berkesinambungan. Pada akhir kualitas proses dapat ditingkatkan menuju pada kualitas pembelajaran dan berakhir membangun kualitas prestasi akademik siswa sesuai dengan upaya dan kemampuan masing masing secara memadai.

\section{LAYANAN BIMBINGAN BELAJAR}

\section{Makna, Tujuan dan Fungsinya}

Makna, tujuan dan fungsi layanan bimbingan belajar mengacu pada berbagai pengalaman dilapangan yang menunjukkan berbagai kesulitan, permasalaan dan bahkan kegagalan yang dialami siswa dalam belajar. Kondisi tersebut tidak selamanya selalu diakibatkan oleh semata mata rendahnya kapasitas intelegensi siswa atau atas kebodohannya, namun bisa jadi kegagalan siswa diakibatkan oleh kurang atau tidak men- dapatkan layanan bimbingan dan konseling yang memadai. Itulah sebabnya eksistensi layanan bimbingan belajar merupakan salah satu bentuk jawaban penting dalam rangka untuk menciptakan keselarasan siswa dalam belajar.

Makna layanan bimbingan belajar mengisyaratkan pada tujuan intinya, yaitu memberikan kemungkinan kepada siswa yang seluas-luasnya untuk mengembangkan sikap dan kebiasaan belajar yang baik, keterampilan belajar dan menyerap materi sesuai dengan tingkat kecepatan, kesulitan, potensi dan perkembangan diri siswa. (Prayitno, 997: 87)

Dengan demikian fungsi utama layanan bimbingan belajaradalah berfungsi pemeliharaan dan pengembangan bagi siswa di sekolah.

\section{Materi Utama Bimbingan Belajar}

Ada beberapa materi utama dalam layanan bimbingan belajar di sekolah. Adapun materi yang akan diakomodir melalui kegiatan layanan bimbingan belajar secara global adalah:

1. Pengenalan siswa yang mengalami masalah belajar, baik aspek kemampuan, motivasi, sikap maupun kebiasaan belajar siswa

2. Pengembangan motivasi, sikap dan kebiasaan belajar siswa

3. Pengembangan keterampilan belajar, membaca, mencatat, bertanya, menjawab dan menulis

4. Pengajaran perbaikan

5. Program pengayaan. (Hallen, 2002: 85)

\section{Belajar Mengajar}

\section{Makna Belajar}

Pemaknaan belajar sangatlah bervariatif sesuai dengan sudut pandang masing masing para ahli pendidikan maupun psikologi. Namun demikian dapat penulis ketengahkan menurut beberapa ahli berikut: 
1. Robert Silverman

Learning is a process in which past experience or practice result in relatively permanent change in an individual's respectory responses, (Robert, E, 1969: 130)

2. Cronback dalam kutipan Ahmadi

Learning is shown by change in behaviors as a result of experience. (Abu Ahmadi, dkk, 1990: 20)

3. Howard L. Kingsley

Learning is a process by which behavior (in broader sense) is original led or change through practice or training". (Abu Ahmadi, dkk, 1990: 20)

Dari berbagai pandangan tersebut di atas, pada prinsipnya bahwa belajar itu adalah suatu proses yang menyebabkan terjadinya suatu perubahan sikap dan perilaku yang melibatkan banyak aspek, baik karena pengalaman dan praktik/ latihan. Proses tersebut dapat terjadi karena kesadaran dan berlangsung lama (process for a long time).

\section{Tujuan Belajar}

Berbagai pandangan tersebut di atas menunjukkkan bahwa pada prinsipnya tujuan belajar adalah:

1. Untuk memperoleh pengetahuan

2. Merupakan upaya untuk menanamkan konsep dan ketrampilan

3. Merupakan upaya untuk membentuk sikap dan perilaku, (Sardiman, 1992: 30)

Dengan demikian pencapaian tujuan belajar adalah untuk menghasilkan (prestasi) yang mencakup:

1. Kepribadian dan sikap tentang hal ihwal pengetahuan, keilmuan dan konsep konsep yang bersifat kognitif

2. Hal ihwal personal yang bersifat afektif

3. Hal ihwal kelakuan dan keterampilan yang bersifat psikomotorik
Ketiga hal ini dalam proses belajar mengajar direncanakan sesuai dengan kontek materi agarmenjadi satu kesatuan yang utuh. Dengan demikian proses internalisasi siswa dalam dalam ilmu psikologi membutuhkan suatu system lingkungan belajar yang kondusif.

\section{Faktor-faktor yang Mempengaruhi Belajar}

Secara psikologis manusia itu memiliki berbagai macam potensi aktualitas yang turut mendukung dan mempengaruhi peristiwa belajar siswa. Potensi psikologis dimaksud adalah:

1. Intelegensi

Kemampuan dan kecakapan ini mencakup kecakapan siswa dalam menghadapi dan menyesuaikan diri dengan situasi yang ada secara ceOpat dan efektif, kemampuan menggunakan konsep abstrak secara efketif, dan kemampuan mengetahui relasi dan mengkajinya secara cepat, (Slameto, 1995: 56). Potensi intelegensi ini sangat besar pengaruhnya terhadap terhadap kualitas proses belajar siswa.

2. Perhatian

Perhatian terhadap suatu materi yang sedang dihadapi merupakan potensi yang sangat mendukung mutu proses belajar siswa. Tingkat keberhasilan dalam belajar tergantung pada sejauhmana konsentrasi siswa terhadap materi pelajaran.

3. Minat

Minat merupakan kecenderungan yang tetap untuk memperhatikan berbagai aktivitas belajar yang diminati. Bila minat siswa terbangun, maka dapat memunculkan suatu partisipasi aktif yang disertai rasa senang sehingga akan memperoleh kepuasan dalam belajar.

4. Bakat

Bakat adalah kemampuan aktual dalam belajar yang menurut Hilgard disebut "the capacity to learn". 
Potensi aktualiteit ini akan tampak setelah siswa belajar dan berlatih. Potensi ini sangat berarti bagi peningkatan kualitas belajar siswa di sekolah.

5. Motivasi

Motivasi belajar pada dasarnya merupakan motor penggerak utama (terutama motivasi instrinsik) bagi siswa, yang dalam bahasa agama disebut sebagai niat yang kuat yang terbangun dalam diri siswa terutama terkait dengan tujuan yang ingin dicapai oleh setiap siswa yang belajar.

6. Kematangan

Menurut James Drever, kematangan adalah "prepareadiness to respond", yaitu suatu fase pertumbuhan dan perkembangan, dimana anak telah memilih readiness, baik fisik maupun psikisnya. Dalam melaksanakan kecakapan-kecakapan belajar, kecakapan ini tergantung pada kematangan setiap siswa.

7. Kesiapan

Kecakapan-kecakapan dalam belajar menentukan kemajuan dalam belajar yang "react" (kesiapan memberi respon). Kesiapan disini dimaksudkan adalah kesiapan secara pisik (kesehatan pisik dan seluruh indera) dan kesiapan psikologis, mental termasuk konsentrasi, stabilitas emosi dan sebagainya.

8. Kelelahan

Kelelahan fisik maupun mental sangatlah berdampak negatif bagi proses belajar siswa

\section{Makna Mengajar}

Mengajar adalah aktivitas menyampaikan pengetahuan dan kecakapan kepada siswa dalam situasi lingkungan yang terorganisir. Di sisi lain, mengajar diartikan sebagai The guidance of Learning activities, teaching is for purpose of aiding the pupil to learn, (Oemar Hamalik, 1992: 58).
Dari Uraian kedua, statement di atas mendeskripsikan bahwa proses belajar mengajar dituntut adanya interaksi edukasi antara guru dan siswa secara memadai, baik melalui kegiatan mengajar ataupun bimbingan belajar. Oleh karena bakat dan interaksi itulah, maka terjadi perubahan sikap dan tingkah laku sebagaimana yang diharapkan.

\section{Prinsip belajar mengajar}

Konsep, kategori, maupun teoriteori belajar menguraikan prinsip-prinsip belajar mengajar yang perlu dijadikan acuan guru dalam melaksanakan proses pembelajaran. Prinsip-prinsip tersebut adalah sebagai berikut:

1. Belajar senantiasa bertujuan yang selaras dengan perkembangan perilaku siswa

2. Belajar didasarkan atas kebutuhan dan motivasi siswa

3. Belajar dilaksanakan dengan latihan daya-daya untuk membentuk hubungan asosiasi melalui penguatan.

4. Belajar bersifat keseluruhan dan menitikberatkan pemahaman, berpikir kritis dan reorganisasi pengalaman.

5. Belajar membutuhkan bimbingan, baik secara langsung oleh guru, maupun secara tidak langsung melalui bantuan pengalaman pengganti.

6. Belajar dipengaruhi oleh faktor internal maupun eksternal siswa

7. Belajar sering dihadapkan pada masalah atau kesulitan yang perlu dipecahkan.

8. Hasil belajar dapat ditransfer ke dalam situasi lain, (Oemar Hamalik, 1992: 54).

Semua prinsip-prinsip di atas dapat dijadikan sebagai acuan dalam upaya peningkatan dan pendayagunaan kualitas proses belajar mengajar di sekolah. 


\section{Pengembangan Individu dan Karakteristik Siswa dalam Proses Belajar Mengajar}

Tujuan pendidikan nasional pada intinya adalah mencerdaskan kehidupan bangsa dan mengembangkan manusia Indonesia seutuhnya, (Depdikbud, 1992: 1992), yaitu individu yang mampu menjangkau lingkup hubungan dengan Tuhan, sesama, lingkungan alam yang konstruktif, sehingga menjadi kepribadian yang terpadu dengan baik, antara cipta, rasa, karsa, jasmani, maupun rohani yang dapat berkembang utuh.

Untuk mewujudkan hal tersebut, maka harus ditempuh dengan kegiatan pendidikan. Sebagai konsekuensinya, proses belajar mengajar harus dikembangkan secara individual, artinya siswa memerlukan perlakuan, strategi dan upaya pelayanan yang berbeda-beda serta bervariasi dengan cara memperhatikan karakteristik siswa.

1. Karakteristik yang berkenaan dengan kemampuan awal siswa (prerequisite skill), dalam hal intelektual, kemampuan berpikir, maupun kemampuan yang bersifat psikomotorik siswa.

2. Karakteristik yang terkait dengan latar belakang keluarga maupun social cultural siswa.

3. Karakteristik yang berkenaan dengan kepribadian yang berbeda-beda baik sikap, minat, perasaan dan lain-lainnya, (Sardiman, 1992: 118).

Informasi dan pemahaman terhadap karakteristik setiap siswa menjadi berguna dalam mengkonstruksikan dan mengorganisir materi, proses interaksi edukasi dalam pelaksanaan pembelajaran, sekaligus memudahkan guru dalam mengembangkan kedewasaan anak didik.

\section{Upaya Peningkatan Kualitas Proses Belajar Mengajar melalui Bimbingan Belajar}

Pengenalan dan pemecahan kesulitan belajar siswa

a. Pengenalan kesulitan belajar (bersifat psikologis)

Secara umum siswa asuh kurang mengenali, memahami dan menyadari sepenuhnya terhadap kesulitan belajar yang selama ini ia rasakan. Oleh karena itu, melalui kegiatan layanan bimbingan belajar (layanan pembelajaran) siswa perlu diperkenalkan dengan berbagai macam kesulitan-kesulitan belajar secara psikologis, seperti:

1. Keterlambatan akademik, yaitu kategori siswa yang memiliki bakat akademik atau memiliki tingkat kecerdasan tinggi, tetapi tidak mampu memanfaatkan kecerdasannya secara optimal.

2. Kecepatan belajar dibandingkan siswa lain pada umumnya sehingga menimbulkan kebiasaan terhadap siswa lain yang dinilai lambat.

3. Sangat lambat dalam belajar akibat memiliki kecerdasan yang kurang memadai.

4. Kurang adanya motivasi dalam belajar.

5. Bersikap dan berkebiasaan yang buruk dalam belajar, (Prayitno, 1994: 91).

6. Anak yang memiliki mental emosional yang kurang sehat, siswa yang demikian dapat merugikan diri sendiri, (Ahmad Mudzakir, 1997: 91). Semua perilaku maladaptif merupakan manifestasi gejala adanya hambatan atau kesulitan belajar siswa. Dengan pengenalan hal-hal tersebut diharapkan siswa asuh dapat merasakan, mengenali dan menyadari kesulitan belajarnya untuk segera dikonsultasikan dengan guru pembimbing di sekolah. 
b. Pengungkapan Masalah atau Kesulitan Belajar Siswa

Guna mengetahui lebih awal kesulitan belajar yang mungkin sedang dirasakan siswa asuhnya, guru pembimbing dapat mengidentifikasi melalui prosedur, pengamatan, analisa hasil belajar, himpunan data siswa, tes intelegensi, bakat, minat atau wawancara dengan siswa. Kemudian analisis laporan dari guru mata pelajaran atau wali kelas dan didiskusikan dengan personil sekolah.

Hasil-hasil pengungkapan tersebut dapat lebih diperkaya lagi melalui konferensi kasus. Semua hasil pengungkapan tersebut disatukan menjadi satu kesatuan informasi dan data untuk dianalisis dan diambil kesimpulannya yang terpadu dan tepat sebagai landasan untuk mencarikan solusinya.

c. Bantuan Pemecahan Kesulitan Belajar

1) Bagi siswa yang memang mengalami keterlambatan akademik yang tidak bisa memanfaatkan kecerdasannya secara optimal, maka perlu diberikan penjelasan khusus bahwa IQ tinggi tidak menjamin kesuskesan belajar, kecuali disertai dengan sikap dan kebiasaan belajar yang baik dan memadai. Di samping perlu ditegasi dengan tugas tertentu secara terprogram, bertanggungjawab dan tepat waktu.

2) Bagi siswa yang mungkin mengalami ketercepatan dalam belajar, layak diberikan tugas-tugas tambahan khusus guna memenuhi tuntutan kebutuhan dan kemampuan belajarnya yang amat tinggi.

3) Bagi siswa yang sangat lambat dalam belajar diperlukan suatu bimbingan dan pengajaran secara khusus dengan alokasi yang waktu yang khusus pula.

4) Bagi siswa yang memiliki motivasi belajar kurang, perlu adanya personal approach dari guru mata pelajaran, wali kelas atau guru pem-bimbing terhadap siswa. Penerapan variasi metode pembelajaran yang disertai penciptaan proses pengajaran kondusif yang dapat menyenangkan dan menenangkan siswa.

5) Bagi siswa yang bersikap dan berkebiasaan buruk dalam belajar diperlukan:

a. Pengubahan sikap dan kebiasaan belajar ke arah yang lebih baik dan produktif.

b. Tindakan-tindakan yang tepat dan edukatif

c. Tegakkan disiplin di dalam proses belajar mengajar

d. Guru tetap komunikatif-interaktif dan edukatif

e. Tegaskan berbagari peran guru dalam proses belajar mengajar

6) Bagi siswa yang memiliki mental emosional kurang sehat.

Sesuai dengan teori Abraham Maslow setidaknya dipenuhi lima kebutuhan psikologis dalam proses belajar mengajar, yaitu kebutuhan rasa kasih sayang, rasa aman, rasa harga diri, rasa keingintahuan, dan rasa aktualisasi diri para siswa melalui proses belajar mengajar karena bisa jadi mereka sangat gersang dari rumah untuk mendapatkan hal tersebut sehingga di sekolah perlu mendapatkan kembali. Dengan pemenuhan hal tersebut, maka kegersangan mental emosional menjadi sejuk kembali dengan tidak merangsang timbulnya gejolak batin siswa.

\section{Upaya Peningkatan Motivasi Belajar Siswa}

Siswa dapat berhasil dalam belajar apabila dirinya memiliki keinginan belajar. Keinginan diri merupakan modal internal untuk melakukan aktivitas belajar. Kehadiran siswa ke sekolah merupakan motivasi yang telah dimiliki. Namun demikian, guru mata pelajaran 
dan giri pembimbing memiliki tugas dan tanggungjawab utama untuk meningkatkan motivasi belajar siswanya secara optimal melalui upaya:

1. Memperjelas tujuan-tujuan belajar

2. Menyesuaikan pelajaran dengan kemampuan bakat dan minat siswa

3. Menciptakan suasana pembelajaran yang menantang, merangsang dan menyenangkan

4. Memberikan reward secara tepat dan benar

5. Menciptakan hubungan yang hangat dan dinamis antara guru dan siswa, guru pembimbing dengan siswa asuhnya, dan sesama siswa.

6. Menghindarkan siswa dari tekanan dan suasana yang menakutkan, menegangkan, mengecewakan, membingungkan, maupun menjengkelkan.

Di sisi lain, Saiful Djamarah merekomendasikan beberapa cara lain untuk memotivasi siswa agar berpartisipasi aktif dalam proses belajar mengajar. Cara tersebut antara lain:

1. Memberikan angka, maksudnya setiap siswa mengerjakan tugas atau ulangan dari guru dapat diberikan nilai sebagai simbol atas prestasinya.

2. Ciptakan suatu kegiatan belajar yang bersifat kompetitif

3. Dalam mengajar guru senantiasa melibatkan keseluruhan siswa mengerjakan tugas dalam rangka berlomba meraih prestasi yang optimal

4. Memberikan ulangan dapat juga dijadikan sebagai alat motivasi siswa untuk belajar

5. Meneguhkan hasrat siswa untuk belajar dengan lebih giat

6. Memperhatikan dan meyakinkan minat siswa dalam belajar

7. Mengkaji hasil-hasil belajar yang diperoleh oleh siswa asuhnya, (Prayitno, 1994: 90).

8. Siswa diberi kesempatan untuk mengetahui hasil belajarnya dari setiap tugas yang diberikan (Saiful Bahri Djamarah, 1994: 41-48).
9. Selalu memberikan pesan dan kesan pada kertas kerja siswa sebagai wujud dorongan normal terhadap upaya siswa dalam belajar

10. Sekolah melengkapi sumber-sumber dan sarana belajar secara memadai

\section{Upaya Pengembangan Sikap dan Kebiasaan Belajar yang Baik}

Sikap dan kebiasaan belajar yang baik merupakan modal awal bagi siswa untuk membangun kualitas proses belajar yang tentunya sangat signifikan menuju prestasi optimal. Mengingat hal ini merupakan faktor fundamental, maka guru pembimbing, guru mata pelajaran, dan orang tua memiliki tugas dan kewajiban untuk menumbuhkembangkan sikap dan kebiasaan belajar yang baik dengan langkah-langkah:

a. Mencari dan menemukan motif yang tepat dalam belajar

b. Selalu menjaga dan memelihara kondisi kesehatan para siswa, baik kesehatan fisik maupun mentalnya

c. Mengatur waktu belajar, baik di sekolah maupun di rumah dengan cara siswa membuat jadwal pelajaran

d. Memilih tempat belajar yang kondusif

e. Siswa ditekankan bahwa belajar menggunakan sumber-sumber belajar yang banyak (buku-buku teks, kamus, maupun referensi lain yang relevan).

f. Dilatih untuk bertanya terhadap halhal yang tidak diketahui (kepada guru, guru pembimbing, wali kelas dan teman)

g. Mengembangkan motivasi dan sikap positif terhadap semua materi yang dipelajari, (Prayitno, 1994: 91).

Upaya-upaya seperti ini tetap harus dipertahankan untuk menciptakan kualitas proses maupun prestasi belajar mengajar di sekolah.

\section{Upaya Peningkatan Keterampilan Belajar Siswa}

Upaya menumbuhkembangkan dan meningkatkan keterampilan belajar sis- 
wa merupakan suatu aspek yang layak untuk dilakukan, baik oleh guru pembimbing terhadap siswa asuhnya, maupun guru mata pelajaran bagi siswanya dalam rangka meningkatkan mutu belajar dan prestasi siswa. Dalam hal ini, Ron Fry telah merekomendasikan berbagai keterampilan belajar yang perlu dikenalkan dan dilatih pada siswa, dalam proses belajar yang dapat diterapkan siswa di kelas ataupun di luar kelas (rumah). Rekomendasi Ron Fry antara lain :

1. Dapat dilakukan di kelas:

a. Melakukan persiapan-persiapan dengan membawa semua materi pelajaran sebelum masuk ke kelas

b. Aktif membuat catatan-catatan keterangan dari guru sebagai dokumentasi

c. Berpartisipasi aktif dalam kelas melalui diskusi kelas, belajar kelompok dan menyampaikan pertanyaan-pertanyaan terhadap materi-materi belajar yang belum dipahami

d. Menulis dan mencatat hasil-hasil laporan kerja yang didiskusikan di kelas

2. Dapat diterapkan di luar kelas (rumah)

a. Mengulang pelajaran dengan menghafal, memasukkan kesan informasi, ataupun penjelasanpenjelasannya.

b. Mencoba meringkas setiap mata pelajaran yang ada

c. Belajar dengan menentukan fokus materi

d. Menggunakan tiga cara dalam membaca bahan pelajaran (membaca cepat dan fokus, mengkritisi materi, membaca dengan disertai hiburan)

e. Membaca bahan pelajaran secara global kemudian merenik.

f. Mengingat apa yang telah dibaca dengan mengenali, mengingat kembali, dan mencoba me-recall kembali

g. Tulislah pertanyaan-pertanyaan dan sekaligus jawabannya untuk meyakini diri sendiri atas penguasaan bahan. Pertanyaan-pertanyaan yang dibuat, apabila tidak bisa menjawab dapat ditanyakan langsung kepada guru mata pelajaran pada saat di kelas, (Ron Fry, 1994: 25-80).

h. Belajar memecahkan soal-soal ulangan dan ujian

i. Membuat jadwal kegiatan belajar secara efektif sesuai dengan kondisi siswa

j. Dengan adanya upaya seperti ini diharapkan siswa dapat menemukan cara-cara belajar yang lebih sesuai dengan kemampuan siswa atau anak asuh. Dengan demikian, setapak demi setapak kualitas proses belajar mengajar semakin meningkat dan dapat menopang prestasi optimal siswa.

\section{Pemberian Layanan Program Per- baikan}

Setelah dengan cermat guru pembimbing menganalisis data akademik siswa asuhnya (laporan kemajuan belajar) yang dinilai masih dibawah standar batas tuntas, maka guru pembimbing bekerja sama dengan guru mata pelajaran untuk menyelenggarakan program perbaikan dengan langkah sebagai berikut:

1. Menyusun Program Perbaikan

Dalam penyusunan program perbaikan, maka diperlukan beberapa hal seperti :
a. Menetapkan tujuan perbaikan (remidial)
b. Menetapkan materi pengajaran remidial
c. Menetapkan metode yang dipakai
d. Menetapkan alokasi waktu pengajaran remidial 
e. Menetapkan sistem evaluasi kemajuan siswa setelah mengikuti program remidial, (Muhibbin Syah, 1999: 171).

2. Pelaksanaan Program Perbaikan Program pengajaran remidial yang telah dirancang segera dilaksanakan dengan bekerjasama dengan guru mata pelajaran yang bersangkutan untuk memberikan kesempatan pada para siswa asuh agar lebih memusatkan perhatiannya pada proses belajar mengajar remidial tersebut. Hal yang menyangkut tempat penyelenggaraan dapat dilakukan di ruangan bimbingan dan konseling dalam rangka membiasakan siswa asuh lebih dekat dengan kegiatan bimbingan dan konseling di sekolahnya.

Pelaksanaan remidial ini diharapkan menerapkan berbagai variasi metode mengajar yang relevan untuk mendukung upaya mengatasi kesulitankesulitan belajar siswa, terutama terhadap penguasaan materi mata pelajaran yang bersangkutan.

3. Pelaksanaan Program Pengayaan

Maksudnya bahwa bagi guru yang telah menyampaikan materi pelajaran telah memenuhi jumlah tatap muka yang dituntut oleh kurikulum dan masih ada waktu luang, maka guru bisa bekerjasama dengan guru pembimbing untuk menyelenggarakan layanan pembelajaran tambahan sebagai materi nilai tambah untuk menghadapi ujian, terkhusus bagi siswa kelas tiga yang sudah butuh

\section{DAFTAR RUJUKAN}

A. Hallen. 2002. Bimbingan dan Konseling. Jakarta: Ciputat Press.

Ahmadi, Abu. 1990. Psikologi Belajar. Jakarta: Rineka Cipta. menyiapkan diri menghadapi ujian sekolah maupun nasional.

\section{PENUTUP}

Pembahasan di atas menunjukkan bahwa pada prinsipnya setiap siswa memiliki permasalahan atau kesulitan belajar yang disebabkan perbedaan potensi yang dimiliki siswa. Kesulitan ini disebabkan oleh faktor internal maupun eksternal dari masing-masing siswa asuh. Setiap kesulitan belajar, baik secara individual maupun kelompok akan dibantu pemecahannya melalui langkahlangkah sebagai berikut :

1. Pengenalan terhadap kesulitan belajar yang dihadapi siswa dalam proses belajar mengajar

2. Upaya diagnosis untuk mengenali, mengungkapkan, serta menentukan faktor penyebab utama kesulitan belajar

3. Upaya pemecahan masalah tahap demi tahap

4. Upaya penumbuhkembangan sikap dan kebiasaan belajar yang baik

5. Upaya memotivasi belajar siswa

6. Upaya mengembangkan keterampilan belajar siswa

7. Upaya menyelenggarakan keterampilan belajar siswa

Semua upaya tersebut merupakan langkah positif untuk mengentaskan kesulitan belajar yang biasa dialami siswa, sekaligus untuk mendukung lajunya kualitas proses belajar mengajar di sekolah dalam meningkatkan prestasi seoptimal mungkin.

Departemen Pendidikan dan Kebudayaan. 1992. Himpunan Peraturan Perundang-Undangan Republik Indonesia. 
Djamarah, Saiful Bahri. 1994. Prestasi Belajar Dan Kompetensi Guru. Surabaya: Usaha Nasional.

Fry, Ron. How To Study. Singapore: Published by Business Tool Box.

Hamalik, Oemar. 1992. Psikologi Belajar Mengajar. Bandung: PT. Sinar Baru.

Mudzakir, Ahmad. 1997.Psikologi Pendidikan. Bandung: CV Pusataka Setia.

Prayitno. 1994. Dasar-dasar Bimbingan dan Konseling. Padang: Jurusan Psikologi Pendidikan dan Bimbingan, Fakultas Ilmu Pendidikan.
1997. Pelaksanaan Bimbingan dan Konseling di Sekolah. Jakarta: PT. Ikrar Mandiri Abadi.

Sardiman. 1992. Interaksi Motivasi Belajar Mengajar. Jakarta: Rajawali Press.

Silverman, Robert. E. Psychology. New York: Appleton Century Craft Educational Bevision Meredith Corporation.

Slameto. 1995. Belajar dan Faktor yang Mempengaruhinya. Jakarta: Rineka Cipta

Syah, Muhibbin. 1999. Psikologi Belajar. Jakarta: CV. Logos. 